\title{
WATER-RISK MANAGEMENT IN TCHOGHA ZANBIL WORLD HERITAGE SITE IN IRAN, WITH A FOCUS ON THE ANCIENT MANAGEMENT SYSTEM
}

\author{
M. Nakhaei ${ }^{1, *}$, M. Correia ${ }^{2}$ \\ ${ }^{1}$ Pasargadae World Heritage Research Center, Iran - m.nakhaee.co@gmail.com \\ ${ }^{2}$ CI-ESG, Centro de Investigação, Escola Superior Gallaecia, Largo das Oliveiras 4920-251 Vila Nova de Cerveira, Portugal - \\ marianacorreia@esg.pt
}

Commission II - WG II/8

KEY WORDS: Water-risk, Management, conservation, earthen heritage, Tchogha Zanbil

\begin{abstract}
:
Water-risk management is one of the most challenging issues in the conservation of earthen sites, because of the inherent weakness of earth to moisture, and also the severe damage after rainfall as a result of a combination of many factors in the deterioration processes. In Tchogha Zanbil World Heritage Site (WHS) in Iran, this problem causes more damage due to the heavy rains that impact the site in a short period of time. The property encompasses a vast area, which makes regular maintenance more difficult. Also, there are insufficient strategies for controlling water runoff on the structures. Archaeological studies have revealed an ancient system for managing surface water at this site which could be compatible and adaptable for further development of the current management system. This study aims to present sustainable approaches in managing water-risk in the Tchogha Zanbil WHS, by identifying the authenticity values, investigating the problems and challenges in the current water-management system, and more importantly, assessing ancient strategies for controlling water, based on archaeological evidence.
\end{abstract}

\section{INTRODUCTION}

Earthen archaeological sites are considered as one of the most vulnerable types of cultural heritage to deterioration (Oliver, 2008). Lack of regular maintenance, the loss of knowledge and techniques, weak management and abandonment have led to accelerating decay and massive destruction of earthen sites (Rainer, 2008). One of the most controversial issues in the conservation of earthen sites is decreasing the rate of damage caused by surface-water or runoff after heavy rainfalls. In the literature, environmental impacts, rain in particular, is described as the main factor responsible for an earthen site's degradation (Rainer, 2008; Fujii et al., 2009; Li et al., 2010; Morel et al., 2012; Richards et al., 2019).

Various conservation approaches have been undertaken around the world to protect earthen monuments against the risk of water. Some of these efforts include modifying earthen material (Oliver, 2008; Kita et al., 2014; Calatan et al., 2015; Eires et al., 2017), improving the inclination of surface (Fodde, Khan, 2010; Shaikh, et al., 2014), coating with materials like geotextile, clay, adobe or mud-plaster (Dehkordi, 2011; Correia et al., 2015), shelters (Stanley-Price, 2002; Oliver, 2008; Ertosun, 2012; Cetin, Funda, 2013), and using sustainable urban drainage systems in archaeological areas (Boogaard et al., 2016).

However, the original inhabitants, with awareness of the vulnerability of earthen structures, have implemented various methods of protection against natural threats, such as rain and runoff. These are the cases of water disposal systems in Ur Ziggurat (Woolley, 1939), or Mohenjo-Daro (Webster, 1962; Jansen, 1989), management system of water resources in Maya

\footnotetext{
* Corresponding author

1 Elamite: inhabitant from ancient Elam from the 3rd millennium to the 4th century BC.
}

in the south of Mesoamerica (Wyatt, 2014), water drainage system for controlling storm water in Babylon (Jones, 1967), using the natural slope to keep the city dry and clean, also, the stepping-stones in the roadways by Etruscans in case of flooding (Burian, Edwards, 2002), long distance water supply channels on steep and unstable slopes in Machu Picchu (Wright, Zegarra, 2000), drainage and protection systems for flooding and storms in the Minoan civilization (Angelakis, Koutsoyiannis, 2003), water management and prevention of unexpected flood damage by using natural hollows, gullies and gutters in Sabra, Jordan (Linder, 2005), prehistoric channels in Thailand to reduce flooding as well as to improve the irrigation system (Parry, 1992).

The Ziggurat of Tchogha Zanbil as one of the most important archaeological monuments of the second millennium BC has demonstrated through minimal intervention (Niroumand et al., 2012), and a clever management of the Elamites ${ }^{1}$, a way to deal with the heavy rains. In spite of the good maintenance application, such as covering the exposed structures with protective mud-plaster, the site has continued to deteriorate due to the lack of a sustainable conservation approach. The rate of annual decay by rain has been so severe that the 1995 and 2000 UNESCO reports have recommended that the consolidation and improvement of the drainage system for the adobe structure be a priority in the conservation plan (UNESCO, 1995; UNESCO, 2000).

The main aim of this research is to investigate risk management of the site after heavy rainfall by re-evaluating the ancient methods of water management, and valorization of ancient techniques for sustainable conservation. 


\section{STUDY SITE: TCHOGHA ZANBIL WORLD HERITAGE SITE}

\subsection{Historical Background}

Tchogha Zanbil is the largest ziggurat outside Mesopotamia and the best preserved of this type of stepped pyramidal monument. The historical World Heritage site is known in Iranian as Chogha Zanbil, and in English as Tchogha Zanbil site. This site was founded by Elamite King Untash-Napirisha (1275-1240), as the religious center of ancient Elam, which was constructed in the margin of Dez River in Khuzestan plain and near Susa city (Neghahban, 1994). The ziggurat originally measured $105.2 \mathrm{~m}$ on each side and had approximately $53 \mathrm{~m}$ in height, in five levels. Presently, only $24.75 \mathrm{~m}$ of the ziggurat height remains (Figure 1).

The ziggurat was built in adobe as the main material and was given a facing of baked bricks to protect from erosion, some of which have cuneiform inscription (Niroumand et al., 2012). The complex was protected by three concentric walls and the innermost wall enclosed the ziggurat. Brick paving also surrounded the ziggurat. At the time of Untash-Gal's death, the city was not completed. Since no subsequent Elamite kings were interested in Tchogha Zanbil (for reasons still unknown), the city lost its importance, except to some priests who continued to live there (Ghirshman, 1966). The real decline and abandonment of the city came with its invasion and destruction by the Assyrian King Ashurbanipal in 640 B.C. Following, the site was abandoned until it was rediscovered in 1935, by Roland de Mecquenem (19351946), being excavated by Roman Girshman (1951-1962) (Garshasbi, Motamedinassab, 2013).

\subsection{Climate}

The main climatic characteristics of the Tchogha Zanbil region was obtained by processing data from Haft-Tepe climatological station for the period of 1961 to 2014, and also the Iran meteorological organization reports from 2011 to 2018. Based on the reports, the annual average precipitation in this region is about $255 \mathrm{~mm}$. The maximum rainfall is during December, January, February, and March (Chart 1).

The intensity-duration-frequency table shows that the highintensity rainfall in this region occurs in a short period of time, which has a more destructive effect. Based on the table, there is a possibility of precipitation occurring at a frequency of 98 $\mathrm{mm}$ in 15 minutes with different return periods (table 1 ). This may be rare in many parts of the world, but by reviewing the 24-hour rainfall data during February 2006, $93.2 \mathrm{~mm}$ of rainfall were reported (Chart 2).
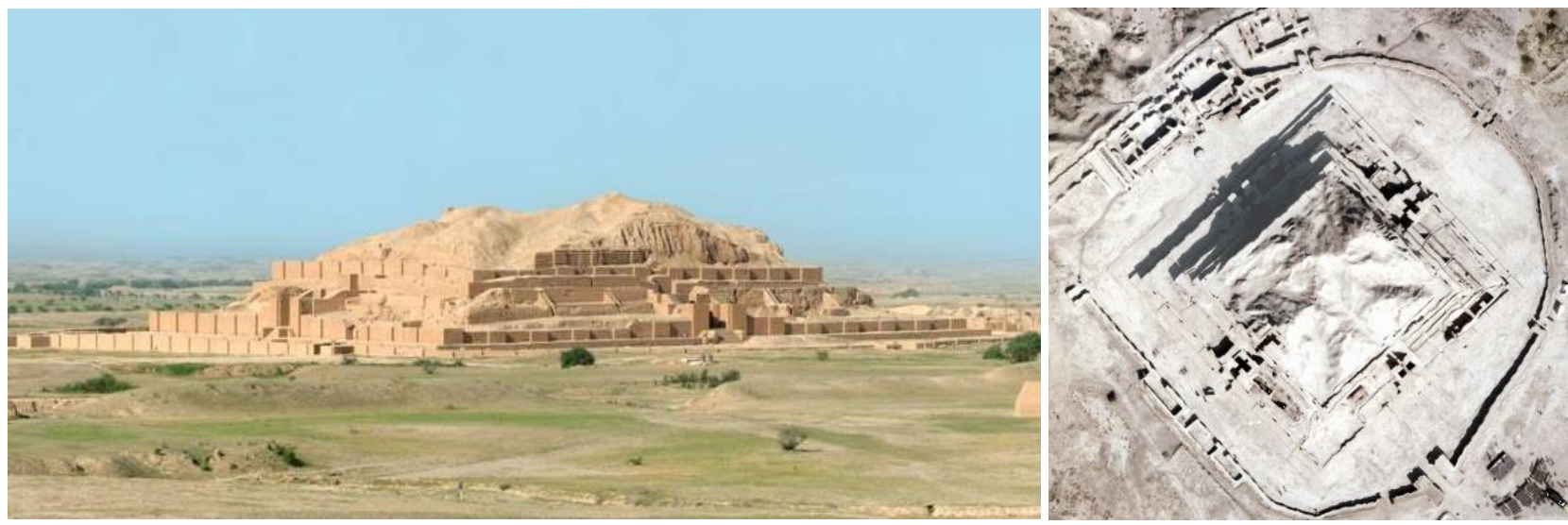

Figure 1. The ziggurat of Tchogha Zanbil World Heritage site and its aerial photo (Archive of Tchogha Zanbil center).

\begin{tabular}{|c|c|c|c|c|c|c|c|c|c|c|c|c|}
\hline & $\mathbf{1 5}$ & $\mathbf{2 0}$ & $\mathbf{3 0}$ & $\mathbf{4 5}$ & $\mathbf{6 0}$ & $\mathbf{9 0}$ & $\mathbf{1 2 0}$ & $\mathbf{1 5 0}$ & $\mathbf{1 8 0}$ & $\mathbf{2 4 0}$ & $\mathbf{3 0 0}$ & $\mathbf{3 6 0}$ \\
\hline $\mathbf{2}$ & 43.9 & 37.5 & 29.8 & 23.4 & 19.6 & 15.1 & 14.2 & 10.8 & 9.6 & 7.9 & 6.8 & 6.0 \\
\hline 5 & 56.6 & 48.4 & 38.4 & 30.1 & 25.2 & 19.5 & 18.3 & 14.0 & 12.4 & 10.2 & 8.8 & 7.8 \\
\hline 10 & 66.2 & 56.6 & 44.9 & 35.2 & 29.5 & 22.8 & 21.4 & 16.3 & 14.5 & 11.9 & 10.3 & 9.1 \\
\hline $\mathbf{2 0}$ & 75.8 & 64.8 & 51.4 & 40.3 & 33.8 & 26.1 & 24.6 & 18.7 & 16.6 & 13.7 & 11.8 & 10.4 \\
\hline $\mathbf{5 0}$ & 88.4 & 75.7 & 60.0 & 47.1 & 39.4 & 30.5 & 28.7 & 21.8 & 19.4 & 16.0 & 13.7 & 12.1 \\
\hline 100 & 98.0 & 83.9 & 66.5 & 52.2 & 43.7 & 33.8 & 31.8 & 24.2 & 21.5 & 17.7 & 15.2 & 13.4 \\
\hline
\end{tabular}

Table 1. Rainfall intensity-duration-frequency table (Malekshahi, 2014).

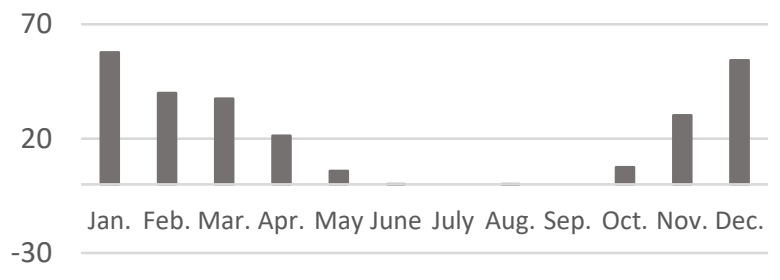

Chart 1. Average monthly rainfall during 1961-2014.

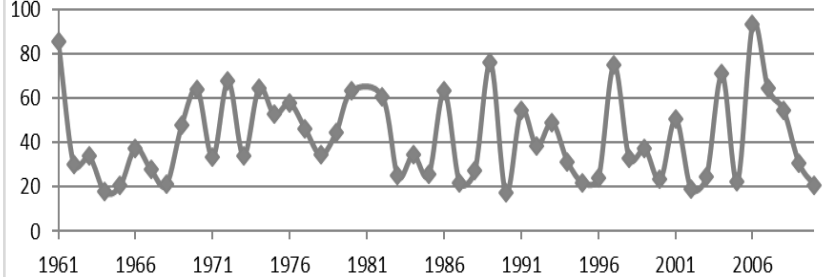

Chart 2. Maximum 24-hour rainfall during 1961-2014 (Malekshahi, 2014). 


\section{ANCIENT METHODS OF WATER MANAGEMENT IN TCHOGHA ZANBIL}

More than half of Tchogha Zanbil's ziggurat has survived for more than 3,000 years, despite the use of vulnerable materials, such as adobe. Elamites had been aware of the vulnerability of different parts of the ziggurat to water, and had integrated a complex drainage system to protect the ziggurat from heavy rainfalls (Ghirshman, 1966). Elamite architects protected the adobe structure of the ziggurat from moisture with a brick façade, and also directed the surface water to the lowest points by gutters and ceramic channels (Ghirshman, 1966). The stepped form of the gutters slowed the water flow and protected the walls from the risk of sudden collapse. Based on Mofidi's studies, the number of original gutters on the first floor was 20 , on the second floor was 9, on the third floor was 5, on the fourth floor was 3, and on the fifth floor was 1 gutter (Mofidi, 2015) (Figures 2 and 3). The number of gutters for each floor was based on preliminary calculations; for instance, based on Mofidi's calculation, the amount of water that each gutter had to drain on the first floor was $499 \mathrm{~m}^{2}$. On the other hand, they tried to place the gutters in a symmetrical manner (Mofidi, 2007). Currently, only the gutters of the first and second floors remain, which makes it difficult to precisely analyze their function.

Another approach of the Elamites to deal with moisture had been the use of natural bitumen in the moisture-related parts, such as gutters, water reservoir, and tomb-palaces. The remains of bitumen at the junction of gutters, and also in some parts of floors along with lime and gypsum are a proof to this case, according with Hosseini-syar (2003). Moreover, Elamites drilled wells for disposal or collecting rainwater in the vicinity of the ziggurat (Ghirshman, 1966; Mofidi, 2007). In total, nine wells were discovered, of which seven were located next to the stairs in the four sides of the ziggurat. Mofidi's studies reveal that these wells were only used to collect gutter water near the stairs. One or two centuries after the construction of the ziggurat, these wells were filled with sediments and were beyond repair. During the renovation, new constructions implemented at the entrance covered the wells under a brick floor (Mofidi, 2007). Furthermore, due to the lack of archaeological evidence, there is no information about water movement between gutters and the horizontal sections.

\section{ASSESSMENT OF HEAVY RAIN DAMAGE}

Due to the environmental factors, heritage sites have been continuously damaged, collapsed and even destroyed in the past thousands of years. Most above-ground sites exposed to the elements have severe damage and some of them have even collapsed (Li et al., 2011). According to the UNESCO's reports, in recent years, one of the most destructive factors in Tchogha Zanbil is the heavy rainfall (UNESCO, 1995; 2000). Surveys indicate that conservation measures in recent years, despite reducing the rate of decay, have failed to fully address the problems, due to the destruction of the ziggurats' upper floors and changes in the surface water conduct system. Therefore, the high rate of erosion can still be observed especially after rain. At present, all surface waters of the ziggurat are evacuated by the remaining gutters, instead of being divided into gutters on each one of the five floors as was originally designed. Therefore, according to the evidence, it can be observed that the most pressure is put on the second-floor gutters. Additionally, based on the archaeological evidence, the central adobe structure was protected by a brick facade against the destruction caused by rainfall. Currently, there is no trace of this brick facade on the upper part of the ziggurat, which is the most vulnerable part to atmospheric downpours. This has led to a change in the surface water disposal system of each floor, based on the Elamite calculations for each gutter (Mofidi, 2007).

In the erosion process during heavy rainfall that occurs mostly in December and January, raindrops splash the mud-plaster, and runoffs wash and transport the detached parts (Smith, Wischmeier, 1957). Afterward, due to the steep slope of the upper part of the ziggurat, small gullies and channels develop and surface runoffs channels into the gullies (Valentin et al., 2005). High hydraulic conductivity of sandy soil accelerates the water transfer (Holden et al., 2006) and increases the problem of water erosion. With continued rainfall for a few days, small holes become large cavities and rainwater penetrates into them, and within a short period of time, the soil erodes and compacts to a significant depth (Poesen et al., 2003). Also, in areas where there is no sloping, fine-grained soils, including clay and silt particles due to low hydraulic conductivity, prevent water movement and start water retention on the surface (Holden et al., 2006). This will lead to subsidence after saturation; therefore, surface waters will also penetrate into these cavities during rainfall. Penetrated water in the created pits and cavities exit at the junction of the adobe structure and brick façade, which causes the massive destruction of the brick façade (Figure 4). The significant lack of mortar in the brick façade, also accelerates this erosion process.

Furthermore, the evaporation of penetrated moisture in the adobe structure of ziggurat, directing the soluble salts to the brick façade, eventually causes salt crystallization and efflorescence (Shaikh et al., 2014; Fodde, Khan, 2010). Moreover, water retention in the different parts of the ziggurat, such as gutters or water pathways, provide a suitable place for plant growth. The growth of plants in these areas, in addition to physical damage of root development, disrupt the function of gutters and water pathways (Hosseini, 2014).

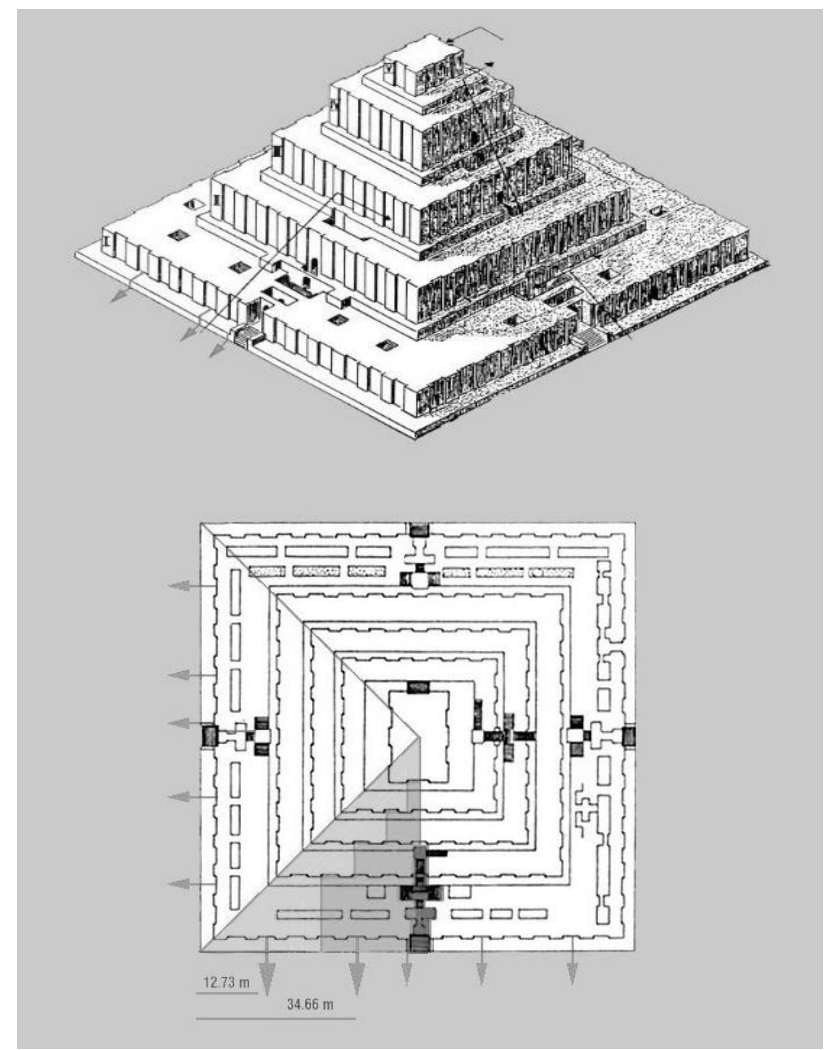

Figure 2. Drainage System in the Tchogha Zanbil ziggurat (Archive of Tchogha Zanbil center). 

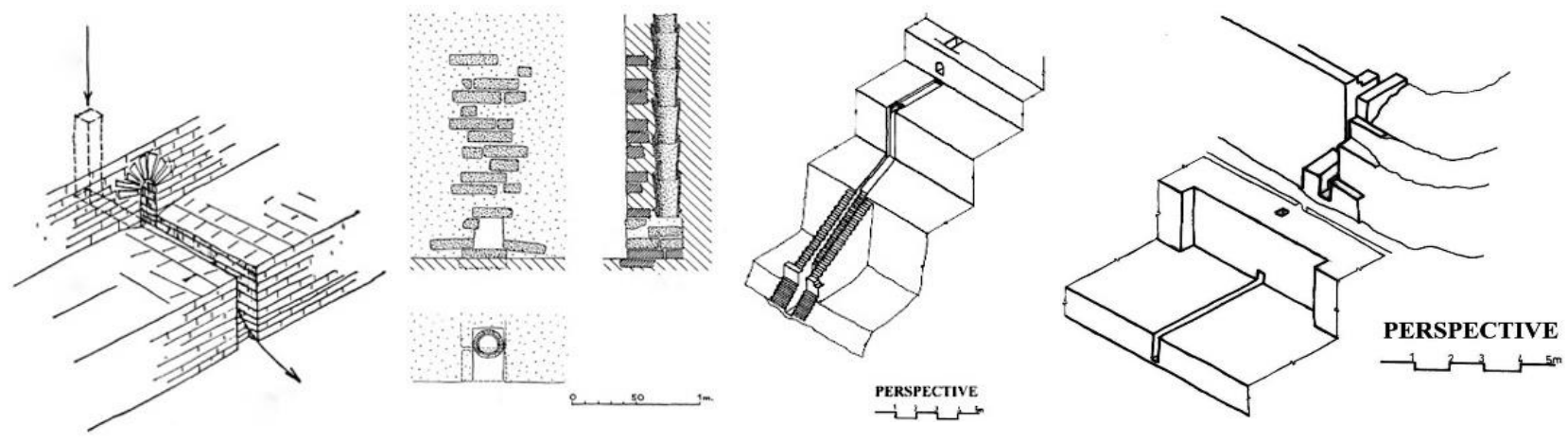

Figure 3. Architectural structure of historical drains in the ziggurat and walls (Archive of Tchogha Zanbil center).
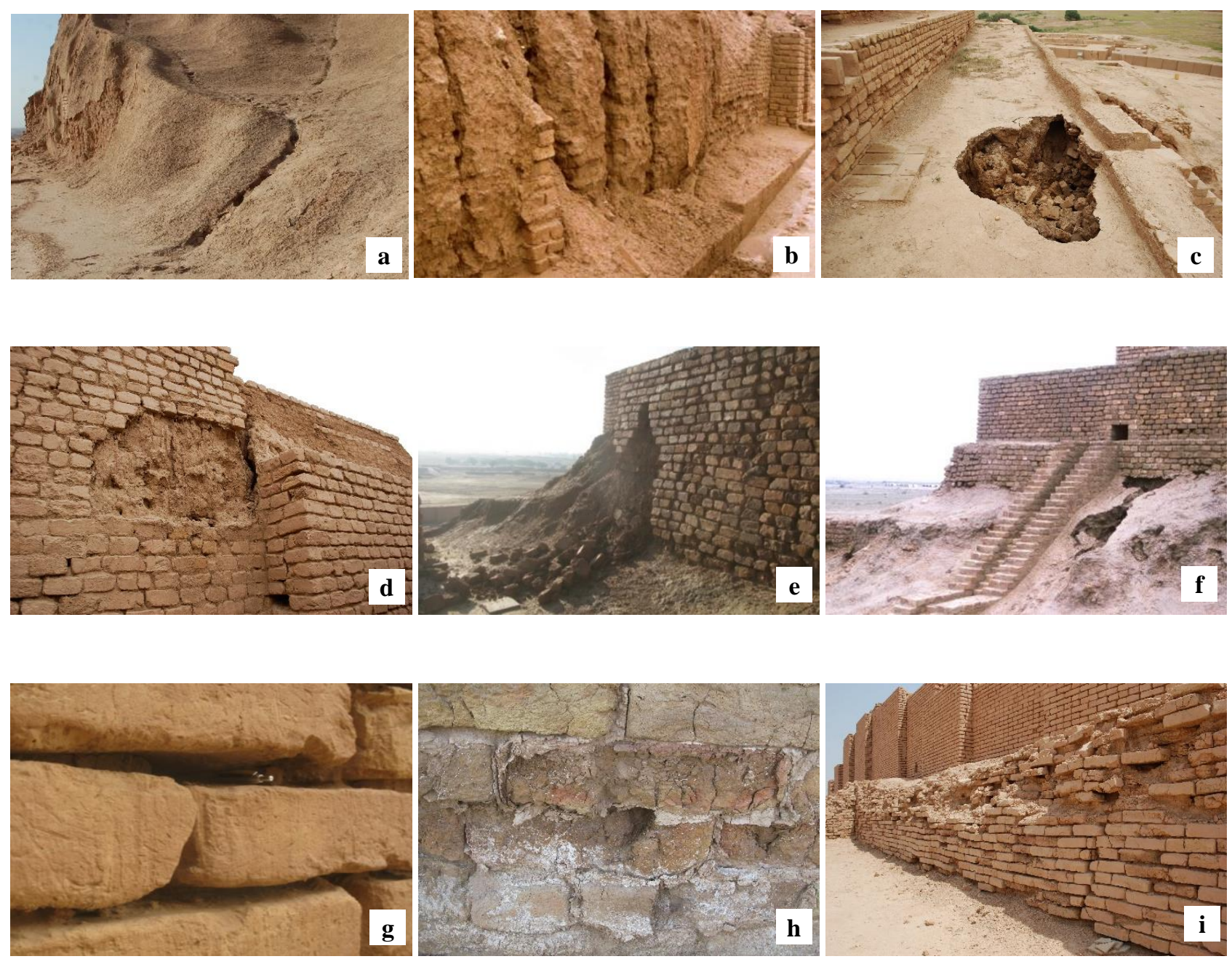

Figure 4. Different deterioration patterns caused by water: a) Rill erosion in the upper part of the ziggurat; b) Erosion of adobe structure as a result of scour (Archive of Tchogha Zanbil center); c) Soil subsidence in a second floor of the ziggurat; d) Detachment and collapse of the brick façade; e) Decay of inner adobe structure and collapse of the brick façade (Archive of Tchogha Zanbil center); f) cavities and erosion close to the gutter due to improper performance of the gutter (Archive of Tchogha Zanbil center); g) Loss of mortar in the brick façade; h) Salt efflorescence; i) Deformation and loss of the brick façade. 


\section{CURRENT MAINTENANCE}

The conservation of earthen structures of Tchogha Zanbil started after the excavation by Roman Girshman in 1961. This was the case of the rearrangement and the restoration of the brick facade of the Ziggurat (Girshman, 1966). In this regard, although these measures were not purely addressed for the purpose of protecting the structure, they were largely able to protect it against environmental conditions, from the time of the excavation until the start of the scientific activities by the Tchogha Zanbil conservation project. The most vulnerable part of the ziggurat, between the years of excavation and the formation of the international conservation project of Tchogha Zanbil, was the upper part of the ziggurat and the adobe sections that were abandoned. After Girshman excavation and prior to the formation of the Tchogha Zanbil project, separate protective measures were also executed by Cultural Heritage Organization of Iran during 1979 to 1990, such as filling gaps with a mixture of soil and lime, as well as repairing the collapsed bricks in some places by cement mortars. Although the above measures were undertaken to preserve the structures, in some cases it was associated with increasing the damage, due to the lack of proper activities.

With the formation of the Tchogha Zanbil Conservation and Preservation Project in 1998, regular and substantial protective measures were undertaken to reduce damages. These measures included: protecting the upper part of the ziggurat with mudplaster, sloping and directing surface water to the gutters, repairing destroyed gutters, repairing the brick facade by calcareous and mud-based mortars, rearranging brick sections and floors for sloping and directing surface water in the distance between the gutters (Figure 5).

\section{DISCUSSION}

Given that storm water rapidly destroys the earthen structures (Endreny, Diemont, 2012), the need of water risk management and risk strategy in such monuments is increasingly needed. Also, conservation measures require re-evaluation due to climate change. For example, in Mohenjo-Daro, due to recent rains, previous interventions on water disposal systems were ineffective and accelerated the structural erosion process (Fodde, Khan, 2017). In the ziggurat of Tchogha Zanbil, despite the conservation and restoration activities carried out in recent years, the damage caused by surface waters is significant because of the destruction of its upper part, decay of original materials, changes in topography and steep slopes, disruption in drainage system, severe water flow, and natural activities by organisms.

It should be noted that some of the conservation measures were addressed to respond to one problem, without considering its side effect on the other parts of the site. This is the case for instance, of directing the extensive amount of water to gutters (more than the gutters capacity) or carrying sediment onto the brick paved ground around the ziggurat. In this regard, article 2.4 of Burra Charter mentions that "Places of cultural significance should be safeguarded and not put at risk or left in a vulnerable state" (ICOMOS, 2013). Establishing water management within archaeological structures is indeed challenging, due to the need for groundwork, as argued by Boogaard et al. (2016). Moreover, one of the strongest points of Tchogha Zanbil is the archaeological evidence of water management systems and applicable techniques to deal with water erosion. This approach, developed by Elamite architects, protected the site for more than 3,000 years. To address the persistent water problem, ancient techniques and strategies could be used, which would respect the site's originality and integrity (ICOMOS, 2013).

As mentioned earlier, the upper part of the ziggurat is considered one of its most vulnerable areas, due to the weakness of the material to the heavy rainfall, and as a result of changes in the surface-water disposal system. Therefore, the erosion process after seasonal rainfall in this area is noticeable, despite extensive maintenance approach. One of the prior measures to control erosion in this area is implementing mudplaster, dividing the various sections of the ziggurat into several basins and directing the surface waters of each basin to one of the gutters. This measure has apparently been able to solve some of the problems. Nevertheless, it created gullies, large cavities, and water penetrated into the adobe structure, contributing to the destruction of ancient layers. These ancient layers had been observed, before the heavy rainfall exposed the upper part of the ziggurat surface, due to the topography and its steep slope, as well as the weakness of the mud-plaster to the heavy rainfall. The protective mud-plaster, in addition to the high cost of implementation and renewal, has not been able to resolve the problem so far. On the other hand, the saturation of the adobe by moisture leads to the weakening of the connection between the brick façade and the inner adobe, also destroying the brick façade. The brick façade and the adobe structure had been interconnected in the past, but after restoration, this connection no longer existed, which can be considered a weak point of the ziggurat.

One of the most innovative efforts of the Elamites dealing with moisture in different parts of the site was the use of natural bitumen along with other materials. The natural bitumen, which is abundant in the Khuzestan province, can function as a modifier for strengthening protective mud-plaster. If it is possible to strengthen the protection mud-plaster against water and rain, a challenging part of the problem will be resolved and the cost of maintenance significantly reduce. Although there is no evidence of the individual use of natural bitumen reinforcing mud-plaster during the Elamite era, it can be used for strengthening mud-plaster in high-risk areas exposed to water erosion, due to the deep knowledge of the Elamite architects in using natural bitumen for waterproofing mortar. In literature, bitumen as a modifier of earthen material has been analyzed in the La Joya archaeological site in Mexico. Long-term monitoring of the bitumen-stabilized experimental walls has confirmed the effectiveness of bitumen as a stabilizer in a tropical environment (Kita et al., 2014).

Stabilized adobe with natural bitumen can also be applied to reduce the steep slope of the upper part of the ziggurat, and as a protective layer in vulnerable areas. The runoff on the steep slope can cause considerable damage to the adobe structure, so water should be gradually drained on a low slope. In MohenjoDaro barriers of sunbaked bricks have been used to reduce the intensity of runoff and also to control soil erosion (Fodde, Khan, 2010).

Concerning the originality, and contrast of the repaired section, the stabilized adobe should be produced with a different dimension than the ancient one. Another measure that the Elamites have taken to conduct runoff into a different part of the site is the use of ceramic water pipe (Tanbushe) and ceramic channels at the bottom of the gutters, which were used in sections with a higher-risk of scouring. 

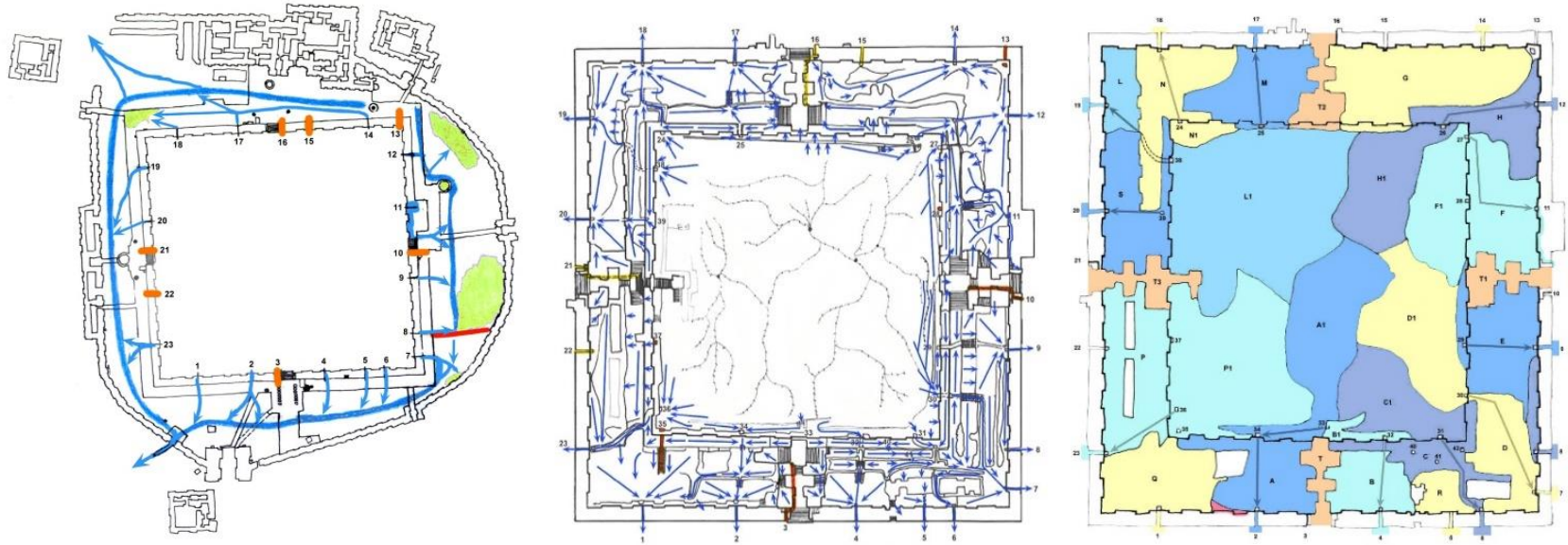

Figure 5. The maps of different basins of the upper part of the ziggurat and their connection to the gutters (Archive of Tchogha Zanbil center)

Observation has shown that in some parts of the ziggurat, with a high intensity of rainfall-runoff, directing the water into ceramic water pipes can reduce the rate of destruction in the brick façade. By reducing the rate of water penetration into the structure, the directed water to the gutters will increase dramatically, so gutters must also be resistant to scour. For this reason, Elamites architects used a layer of natural bitumen along with gypsum and lime as mortar. This would increase the strength of the gutters against the severe runoff, which could also be applied to enhance the strength of the gutter bricks.

Another problem of the Tchogha Zanbil ziggurat, which is directly related to rainfall and moisture content, is the lack of mortar between the bricks. Girshman (1966) used a combination of gypsum and earth mortar for the restoration of the brick façade. At present, due to rainfall and runoff on the brick façade, a significant amount of mortar has been lost, which has increased the weakness of the brick façade. Nonetheless, it is of great importance to protect the unique and exceptional brick cuneiform inscriptions from the original brick façade.

Moreover, using any mortar can cause irreparable damage, due to the high porosity of the bricks and their vulnerability to climate change. It is possible to analyze the ancient formula of mortar including gypsum, lime, and bitumen to respect the Elamite heritage and to reduce the rate of erosion. Due to the high porosity of the bricks, the inner soluble salts of the adobe, the high air temperature in summer and the constant humidity in winter, extensive laboratory and field studies are required to examine the mortar formula.

Finally, the brick sedimentation that paved ground around the ziggurat, which was caused by detached soil elements and the rainfall transmission, leads to salt crystallization and efflorescence in the bricks. This is mostly visible on the south part of the ziggurat. Elamite architects used wells, especially in the vicinity of the ziggurat stairs, to prevent this sedimentation and collect runoffs. Archaeological evidence indicates that most of these wells were filled by rainfall sediments during the Elamite period (Mofidi, 2007). Unfortunately, they practically lost their function. Whereas one of the problems of this site is the sedimentation by rainwater, the re-using of wells does not seem to be an appropriate solution.
In this regard, in addition to strengthening the protective earth plaster, the use of natural slopes to direct surface water from the first enclosure wall looks like the most appropriate option.

\section{CONCLUSION}

This study reveals that for a sustainable conservation plan, the site should consider the ancient knowledge and strategies of preservation and maintenance. The ziggurat of Tchogha Zanbil, has always been affected by floods and seasonal rainfall from the very beginning of its construction. This had been associated with the Elamites' creativity in providing a complex drainage system, in order to protect the ziggurat from heavy winter rains.

Regarding water-risk management, Elamite architects undertaken several preventive actions, such as to protect vulnerable adobe structures with a brick facade, to create stepped forms for gutters, to build wells, to develop a deep knowledge of the bitumen function for water-resistance purposes and to use ceramic water pipes for conducting water runoff.

Nowadays, despite various conservation efforts after excavation, the deterioration process continues to threaten the site, due to a lack of a sustainable conservation plan. The destruction of the upper floors of the ziggurat, disrupts the connection of gutters and surface water. Therefore, it seems essential to have a general view of the ziggurat, as a whole and to study again the water runoffs, from the peak of the ziggurat to the first enclosure wall, as did the Elamites. There is a need to support such measures with analytical work, to enable a scientific assessment of the effectiveness of the proposed methods.

Moreover, this study has only dealt with the problem of rainwater in the ziggurat and the first enclosure wall (high-risk area). Disposal of the surface water after the first enclosure wall, due to the lack of archaeological evidence, requires further studies. Finally, the concept of monitoring is essential when considering precise planned conservation measures facing heavy rain. The idea is to learn from ancient knowledge, and to bring it to practice. This becomes crucial for the survival of Tchogha Zanbil site, especially facing the challenges of climate change. 


\section{REFERENCES}

Afkhami, B., 2019: Phenomenology of Chogha Zanbil Ziggurat Journal of ancient history and archaeology, 6(1).

Angelakis, A. N., Koutsoyiannis, D., 2003: Urban water engineering and management in Ancient Greece. The encyclopedia of water science, 999-1008.

Avrami, E., Mason, R., de la Torre, M., 2000: Report on research. Values and Heritage Conservation: research report. Los Angeles: The Getty Conservation Institute, 3-11.

Boogaard, F., Wentink, R., Vorenhout, M., de Beer, J., 2016: Implementation of Sustainable Urban Drainage Systems to Preserve Cultural Heritage-Pilot Motte Montferland. Conservation and management of archaeological sites, 18(1-3), 328-341.

Burian, S. J., Edwards, F. G., 2002: Historical perspectives of urban drainage. In Global solutions for urban drainage (pp. 1-16).

Calatan, G., Hegyi, A., Dico, C., Mircea, C., 2015: Surface waterproofing methods of clay bricks used in vernacular construction. Green Buildings Technologies and Materials.

Correia, M., Guerrero, L., Crosby, A., 2015: Technical Strategies for Conservation of Earthen Archaeological Architecture. In Conservation and Management of Archaeological Sites, 17:3, 224-256, DOI: 10.1080/13505033.2015.1129799

Çetin, Y., Funda, N., 2013: Architectural design characteristics of protective structures at archaeological sites and their impact on conservation of remains. Izmir, Izmir Institute of Technology.

Dehkordi, M. H., Vatandoust, R., Madjidzadeh, Y., Kashi, M. G., 2011: The archaeological site of Konar Sandal, Jiroft, Iran: Conservation of earthen architecture. In Terra 2008: Proceedings of the 10th international conference on the study and conservation of earthen architectural heritage, Bamako, Mali, February 1-5, 2008 (pp.183-188).

De la Torre, M., 2013: Values and heritage conservation. Heritage \& Society, 6(2), 155-166.

Eires, R., Camões, A., Jalali, S., 2017: Enhancing water resistance of earthen buildings with quicklime and oil. Journal of cleaner production, 142, 3281-3292.

Endreny, T. A., Diemont, S. A., 2012: Methods for assessing stormwater management at archaeological sites: Copan Ruins case study. Journal of Archaeological Science, 39(8), 26372642 .

Ertosun, A. I., 2012: Evaluation of protective structures in archaeological sites for in situ conservation of architectural remains and artifacts. Master diss. Ankara, Middle East Technical University.

Fodde, E., Khan, M. S., 2010: Moenjodaro: a world heritage site at risk. The Historic environment: policy \& practice, 1(1), 52-69.

Fodde, E., Khan, M. S., 2017: Affordable monsoon rain mitigation measures in the World Heritage site of Moenjo-daro, Pakistan. International Journal of Architectural Heritage, 11(2), 161-173.
Fujii, Y., Fodde, E., Watanabe, K., Murakami, K., 2009: Digital photogrammetry for the documentation of structural damage in earthen archaeological sites: The case of Ajina Tepa, Tajikistan. Engineering Geology, 105(1-2), 124-133.

Garshasbi, R., Motamedinassab, A., 2013: Physical Consideration of the Water Filtration in Choghazanbil Ziggurat. Journal of Novel Applied Sciences, 2 (11), 622-626.

Ghirshman, R., 1966) Tchoga Zanbil (Dur-Untash). Volume I: La Ziggurat. Librairie Orientaliste Paul Geuthner. Paris.

Holden, J., West, L. J., Howard, A. J., Maxfield, E., Panter, I., Oxley, J., 2006: Hydrological controls of in situ preservation of waterlogged archaeological deposits. Earth-Science Reviews, 78(1-2), 59-83.

Hosseini, Z., 2014: Systematic control of two weed species Capparis spinosa and Prosopis stephaniana in Choqazanbil and Haft-tepe historical site. Choqazanbil World Heritage Research Center.

Hosseini S, H., 2003: Mortar Studies in Chogazanbil Project. Choqazanbil World Heritage Research Center. Unpublished report.

ICOMOS, 1994: The Nara document on authenticity. Paris: ICOMOS.

ICOMOS, 2013: The Burra Charter: The Australia ICOMOS charter for places of cultural significance 2013. Australia ICOMOS Incorporated.

Jansen, M., 1989: Water supply and sewage disposal at MohenjoDaro. World Archaeology, 21(2), 177-192.

Jokilehto, J., 2000: Conservation of Chogha Zanbil (Mission Report). Available at: whc.unesco.org/en/documents/140020

Jones, D. E., 1967: Urban hydrology-a redirection. Civil Engineering, 37(8), 58.

Kita, Y., Daneels, A., Romo de Vivar, A., 2014: Pre-Columbian earthen construction technology and its application to conservation. In 9th International Conference on Structural Analysis of Historical Constructions. SAHC2014, Mexico City (pp. 1-11).

Li, L., Shao, M., Wang, S., Li, Z., 2011: Preservation of earthen heritage sites on the Silk Road, northwest China from the impact of the environment. Environmental Earth Sciences, 64(6), 16251639.

Lindner, M., 2005: Water supply and water management at ancient Sabra (Jordan). Palestine exploration quarterly, 137 (1), 33-52.

Malekshahi-fard, H., 2014: Cooperation project of Sardar-Abad natural and historical protected area. Choqazanbil World Heritage Research Center.

Mofidi-Nasrabadi, B., 2007: Archäologische Ausgrabungen und Untersuchungen in $\breve{C}$ g̀ā Zanbil. Agenda-Verlag.

Mofidi-Nasrabadi, B., 2015: Reconstruction of the Ziqqurrat of Chogha Zanbil. Elamica 5. 37-51. 
Morel, J. C., Bui, Q. B., Hamard, E., 2012: Weathering and durability of earthen material and structures. In Modern Earth Buildings (pp. 282-303). Woodhead Publishing.

Neghahban, E., 1994: Excavation in Haft Tappeh and Khuzestan Plain. Iranian Cultural Heritage Organization Publications, Tehran.

Niroumand, H., Zain, M. F. M., Jamil, M., 2012: The important role of Chogha Zanbil in earth architecture based on material, structural and architectural aspects. In Advanced Materials Research (Vol. 457, pp. 395-398). Trans Tech Publications.

Oliver, A., 2008: Conservation of earthen archaeological sites. Terra Literature Review, 80.

Oliver, A., 2008: Modified Earthen Materials. Terra Literature Review, 97.

Paolini, A., Vafadari, A., Cesaro, G., Quintero, M. S., Van Balen, K., Pinilla, O. V., 2012: Risk management at heritage sites: A case study of the Petra World Heritage site. Paris: UNESCO.

Parry, J. T., 1992: The investigative role of Landsat-TM in the examination of pre-and proto-historic water management sites in Northeast Thailand. Geocarto International, 7(4), 5-24.

Poesen, J., Nachtergaele, J., Verstraeten, G., Valentin, C., 2003: Gully erosion and environmental change: importance and research needs. Catena, 50(2-4), 91-133.

Rainer, L., 2008: Deterioration and pathology of earthen architecture. Terra Literature Review, 45.

Richards, J., Zhao, G., Zhang, H., Viles, H., 2019: A controlled field experiment to investigate the deterioration of earthen heritage by wind and rain. Heritage Science, 7(1), 51.

Roche, C., 1986: Les ziggurats de Tchogha Zanbil. Fragmenta historiae elamicae, Paris, 191-197.

Shaikh, J. M., Tania, A., Hyder, A., 2014: Study of Methods to Lower the Water Table at Mohen Jo Daro (Green Agriculture). Universal Journal of Agricultural Research, 2(1), $1-10$.

Smith, D. D., Wischmeier, W. H., 1957: Factors affecting sheet and rill erosion. Eos, Transactions American Geophysical Union, 38(6), 889-896.

Stanley-Price, N. P., Jokilehto, J., 2002: The decision to shelter archaeological sites: Three case-studies from Sicily. Conservation and management of archaeological sites, 5(1-2), 19-34.

UNESCO-WHC., 1995: Convention Concerning the Protection of the World Cultural and Natural Heritage. Nineteenth Session. Paris: UNESCO-WHC.

UNESCO-WHC., 2000: Convention Concerning the Protection of the World Cultural and Natural Heritage. Bureau of the World Heritage Committee, Twenty-fourth session. Paris.

UNESCO-WHC., 2015: Convention Concerning the Protection of the World Cultural and Natural Heritage. World Heritage Committee, Thirty-ninth session. Bonn, Germany.
Vafadari, A., Philip, G., Jennings, R., 2017: Damage Assessment and Monitoring of Cultural Heritage Places in a Disaster and Post-Disaster Event - a Case Study of Syria. International Archives of the Photogrammetry, Remote Sensing \& Spatial Information Sciences, 42.

Valentin, C., Poesen, J., Li, Y., 2005: Gully erosion: impacts, factors and control. Catena, 63(2-3), 132-153.

Webster, C., 1962: The sewers of Mohenjo-Daro. Research Journal of the Water Pollution Control Federation, 116-123.

Woolley, C. L., 1939: The Ziggurat and its Surroundings (Ur Excavations 5). London: British Museum.

Wright, K. R., Zegarra, A. V., 2000: Machu Picchu: A civil engineering marvel. American Society of Civil Engineers.

Wyatt, A. R., 2014: The scale and organization of ancient Maya water management. Wiley Interdisciplinary Reviews: Water, 1(5), 449-467. 